\title{
SUSPECTED CLINICAL TOXOPLASMOSIS IN PET RABBITS (ORYCTOLAGUS CUNICULUS) IN LIMA, PERU
}

(Suspeita de toxoplasmose clínica em coelhos de estimação (Oryctolagus cuniculus) em Lima, Peru)

Jesús Lescano ${ }^{1 *}$, Miryam Quevedo ${ }^{1}$

1Universidad Nacional Mayor de San Marcos, Lima, Peru. *Corresponding author: xtianlescano@gmail.com

RESUMO: A toxoplasmose é uma doença prevalente entre coelhos em muitas áreas do mundo. No entanto, a sua apresentação clínica é muito incomum. $\mathrm{Na}$ América do Sul, a prevalência de toxoplasmose em coelhos é desconhecida e os relatórios clínicos desta doença são escassos ou inexistentes. Anticorpos contra Toxoplasma gondii foram encontrados em quatro coelhos de estimação que foram recebidos na Clínica de Animais Selvagens e Exóticos, Faculdade de Medicina Veterinária, Universidad Nacional Mayor de San Marcos (Lima, Peru). Estes animais foram recebidos em cerca de um ano e pertenciam a diferentes proprietários. Os motivos mais comuns para a apresentação foram anorexia/hiporexia e dificuldade em andar. O sinal clínico mais freqüentemente observado foi a mialgia. Todos os coelhos apresentaram anemia, linfopenia e aumento da creatinina. Os 75\% (3/4) dos pacientes morreram ou foram humanamente eutanaziados. Este artigo descreve a presença de anticorpos contra $T$. gondii em coelhos clinicamente doentes pela primeira vez no Peru. Com base nestas observações, recomenda-se a pesquisa sobre prevalência de toxoplasmose em coelhos e seus fatores de risco associados.

Palavras-chave: Animais exóticos; creatinina; Lagomorpha; protozoários; Toxoplasma gondii

ABSTRACT: Toxoplasmosis is a prevalent disease among rabbits in many areas of the world. However, its clinical presentation is very uncommon. In South America, prevalence of toxoplasmosis in rabbits is unknown and clinical reports on this disease are scarce or inexistent. Antibodies against Toxoplasma gondii were found in four pet rabbits, which were received at the Wild and Exotic Animals' Clinic, School of Veterinary Medicine, Universidad Nacional Mayor de San Marcos (Lima, Peru). These animals were received over about one year and belonged to different owners. The most common reasons for presentation were anorexia/hyporexia and difficulty to walk. The most frequently observed clinical sign was myalgia. All rabbits presented anemia, lymphopenia, and increased creatinine. The $75 \%(3 / 4)$ of patients died or were humanely euthanized. This article describes the presence of antibodies against $T$. gondii in clinically ill rabbits for the first time in Peru. Based on these observations, research on prevalence of toxoplasmosis in rabbits and its associated risk factors are recommended.

Keywords: Exotic animals; creatinine; Lagomorpha; protozoa; Toxoplasma gondii 
Suspected clinical toxoplasmosis in pet rabbits (Oryctolagus cuniculus) in Lima, Peru

\section{INTRODUCTION}

Toxoplasmosis is among the most common zoonotic diseases worldwide (it is present in about 30 to $50 \%$ of world population); and it is also considered an important opportunistic infection in immunocompromised patients (Torrey and Yolken, 2003; Barakat, 2007; Dubey and Jones, 2008; Muñoz-Zanzi et al., 2010; Flegr et al., 2014). The etiologic agent is Toxoplasma gondii, an obligate intracellular protozoan first described in 1908 by Nicolle and Manceaux in USA and by Splendore in Brazil (Black and Boothroyd, 2000; Barakat, 2007; CenciGoga et al., 2011). This parasite infects the intestine of domestic and wild felids, which are its definitive host (Méndez et al., 2011). Most birds (recorded in more than 30 species) and mammals (recorded in more than 300 species) are potential intermediate hosts. Australian marsupials, arboreal primates and lemurs are highly susceptible (Bowman et al., 2002; Almería et al., 2004; Flegr et al., 2014; Carlson-Bremer et al., 2015). Moreover, T. gondii has recently been detected in snakes, being the first record of natural infection by this parasite in reptiles (Nasiri et al., 2016).

Toxoplasmosis is prevalent in domestic rabbits in USA, Mexico, Egypt, Czech Republic, Germany, and China (Aghwan et al., 2010; Bergmann et al., 1980; Dubey et al., 1992; Percy and Barthold, 2007; Ashmawy et al., 2011; Fisher and Carpenter, 2012; AlvaradoEsquivel et al., 2013; Varga, 2014; Meng et al., 2015). Infection is usually asymptomatic and clinical disease is associated with immunosuppression (Dubey et al., 1992; Dubey and Jones, 2008; Lennox and Kelleher, 2009; Fisher et al., 2012; Varga, 2014); hence it is considered to be an uncommon cause of neurological disease in rabbits (Oryctolagus cuniculus) (Percy and Barthold, 2007; Fisher and Carpenter, 2012). Rabbits can get $T$. gondii when eating grass contaminated with sporulated oocysts originated in cat feces, and congenital transmission of $T$. gondii has been described in rabbits (Harkness et al., 2010a; Fisher and Carpenter, 2012; van Praag, 2014; Varga, 2014). While toxoplasmosis is potentially zoonotic, the only known way of transmission from rabbit to humans is by handling or ingesting contaminated undercooked or raw meat. Toxoplasmosis is not spread by rabbits feces (Lennox and Kelleher, 2009; Varga, 2014).

Toxoplasmosis in rabbits has three presentations: latent infection (i.e. asymptomatic, commonly seen in immunocompetent adult rabbits), chronic infection (i.e. old rabbits presenting cyst in muscles and nervous tissue, with intermittent episodes of clinical disease which are associated to immunosuppression and stress), and acute infection (i.e. commonly seen in young rabbits, which die in about 2 to 8 days post infection) (van Praag, 2014). Clinical signs are frequently observed in acute episodes of disease, among them are described: anorexia, pyrexia, ataxia, hind limbs paresis, tetraplegia, seizures, and death (Fisher and Carpenter, 2012; Varga, 2014). Survival rates are very low and prognosis is poor due to the sudden and quick progression of parasitosis (van Praag, 2014).

Information related to clinical cases of toxoplasmosis in rabbits is scarce in South America and practically non-existent in Peru. This article describes the clinical presentation, clinicopathological findings, and therapeutics in pet rabbits presenting clinical manifestation suggesting toxoplasmosis and showing antibodies against $T$. gondii.

\section{MATERIAL AND METHODS}

Review of clinical records

A systematic review of clinical records of pet rabbits received from 
January to December 2015 at the Wild and Exotic Animals' Clinic, School of Veterinary Medicine, Universidad Nacional Mayor de San Marcos. Informed consent from each rabbit's owner was obtained in order to use information from clinical records. Data from rabbits with both serologic diagnosis and clinical signs of toxoplasmosis were selected. Sex, age, diet, living with cats, clinical signs, hematological findings, biochemical findings, therapeutics, outcome, and survival time were recorded. This study was approved by the Ethics and Animal Welfare Committee, School of Veterinary Medicine, Universidad Nacional Mayor de San Marcos (Authorization No. 017-2016).

\section{Statistical Analysis}

Mean, standard deviation, and range were estimated for age and survival time data. Sex, clinical signs, hematological findings, and biochemical findings were summarized using frequencies.

\section{RESULTS}

A total of 255 clinical records were reviewed, in which four cases of rabbits with clinical diagnosis of suspected toxoplasmosis were found. Hence, frequency of suspected clinical toxoplasmosis in rabbits received at our clinic during 2015 was 1,6\% (Cl95\% 0,4 - 4,0\%). Clinical data of these rabbits are presented in Table 1. Mean age of rabbits with toxoplasmosis was $5,25 \pm$ 1,5 (range $4-7$ ) years and $75 \%(3 / 4)$ were female. Survival time (from clinical signs presentation to death or humane euthanasia) was 6,7 $\pm 1,2$ (range 1-7) days and only in one of the four cases the patient recovered from illness. The only recovered rabbit was treated during 6 weeks, until clinical signs disappeared and antibodies against $T$. gondii were not detected. Such animal was rechecked 6 months later and was found clinically healthy but in poor body condition.

Table 1. Clinical, hematological, and biochemical data of rabbits presenting antibodies against $T$. gondii.

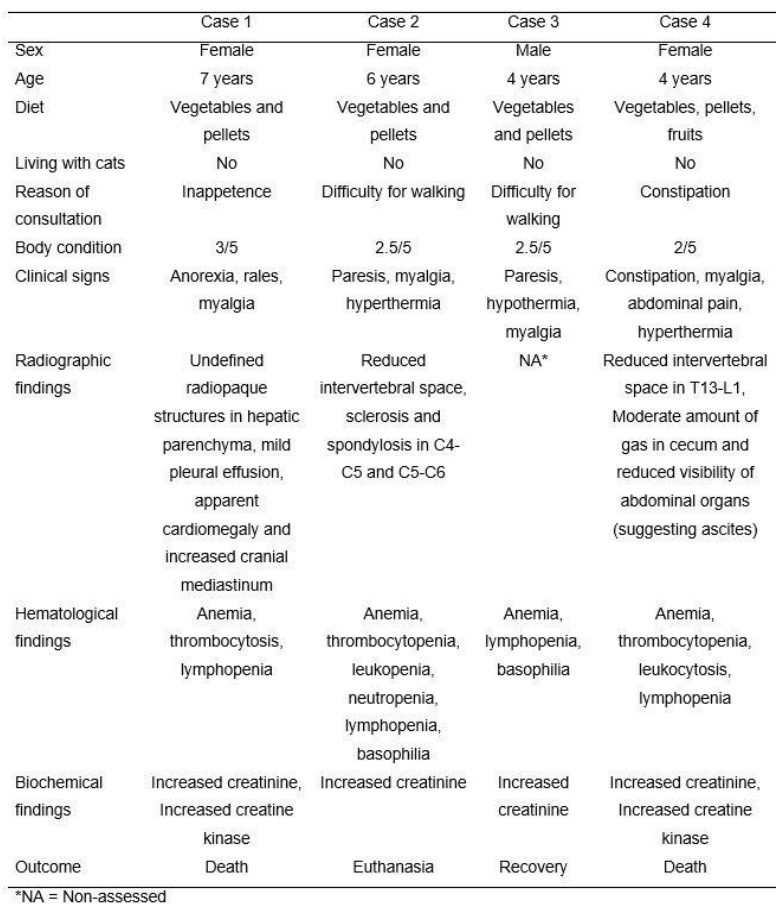

All rabbits presented anemia and lymphopenia. Other hematological findings were basophilia (3/4), thrombocytopenia (2/4), leukopenia $(1 / 4)$, leukocytosis $(1 / 4)$, neutropenia $(1 / 4)$, thrombocytosis $(1 / 4)$, eosinophilia $(1 / 4)$, and neutrophilia (1/4). Increased creatinine was observed in all animals, followed in frequency by increased creatine kinase (2/4). Hematological and biochemical findings are detailed in Table 2. Serological diagnosis was performed using the Indirect Hemagglutination test and titration with 2-Mercaptoethanol (Toxotest $\mathrm{HAI}^{\circledR}$, Wiener Lab, Argentina) following manufacturer's instructions. IgM was detected only in one animal (i.e. Case 4), thus revealing acute infection. Such diagnosis was based on antibodies titration decreasing in two dilutions when using 2-Mercaptoethanol in comparison 
Suspected clinical toxoplasmosis in pet rabbits (Oryctolagus cuniculus) in Lima, Peru

to titer observed without it. These results are shown in Table 3.

Table 2. Hematological and biochemical results of seropositive rabbits.

\begin{tabular}{|c|c|c|c|c|c|}
\hline \multirow[t]{2}{*}{ Analyte (unit) } & Case & Case & Case & Case & Reference \\
\hline & 1 & 2 & 3 & 4 & range $a, b$ \\
\hline Erythrocytes (106/ul) & 6 & 4 & 3 & 3 & $4-7.2$ \\
\hline Hemoglobin (g/dL) & 8.7 & 8.4 & 9.5 & 7 & $10-15.5$ \\
\hline Packed Cell Volume (\%) & 38 & 28 & 31 & 26 & $36-48$ \\
\hline Mean Corpuscular Volume (fL) & 63.3 & 70 & 103.3 & 86.7 & - \\
\hline Mean Corpuscular & 14.5 & 21 & 31.7 & 23.3 & - \\
\hline \multicolumn{6}{|l|}{ Hemoglobin ( $g / d L)$} \\
\hline Mean Corpuscular & 22.9 & 30 & 30.6 & 28 & - \\
\hline \multicolumn{6}{|l|}{ Hemoglobin Concentration $(\mathrm{g} / \mathrm{dL})^{*}$} \\
\hline Platelets (103/uL) & 916 & 180 & 372 & 50 & $200-1000$ \\
\hline Leukocytes (cells/uL) & 5380 & 4080 & 7400 & 22300 & $7000-13500$ \\
\hline Segmented neutrophils (\%) & 89 & 52 & 59 & 88 & $20-35$ \\
\hline Segmented neutrophils (cells/uL) & 4788 & 2122 & 4366 & 19624 & - \\
\hline Lymphocytes (\%) & 8 & 41 & 37 & 8 & $55-80$ \\
\hline Lymphocytes (cells/uL) & 430 & 1673 & 2738 & 1784 & - \\
\hline Monocytes (\%) & 0 & 2 & 1 & 1 & $1-4$ \\
\hline Monocytes (cells/uL) & 0 & 82 & 74 & 223 & - \\
\hline Eosinophils (\%) & 3 & 2 & 1 & 2 & $0-4$ \\
\hline Eosinophils (cells/uL) & 161 & 82 & 74 & 446 & - \\
\hline Basophils (\%) & 0 & 3 & 2 & 1 & $2-10$ \\
\hline Basophils (cells/uL) & 0 & 122 & 148 & 223 & - \\
\hline Creatinine (mg/dL) & 2 & 2.6 & 2.4 & 3.2 & $0.8-1.8$ \\
\hline Alanine aminotransferase (UI/L) & 160 & 40 & 16 & 114 & $112-350$ \\
\hline Total proteins $(\mathrm{g} / \mathrm{dL})$ & 5.3 & $N A^{*}$ & $N A^{*}$ & 5.7 & $2.8-10$ \\
\hline Albumin (g/dL) & 3 & $N A^{*}$ & $N A^{*}$ & 3.1 & $2.7-4.6$ \\
\hline Creatine kinase (UI/L) & 799 & 590 & 667 & 1990 & $<700$ \\
\hline
\end{tabular}

Therapeutic protocol used in all cases was trimethoprim/ sulfamethoxazole $(40 \mathrm{mg} / \mathrm{kg} \mathrm{PO} \mathrm{q} / 12 \mathrm{~h} \mathrm{x}$ 28 days) (Bactrim ${ }^{\circledR}$, Roche, Switzerland) and doxycycline $(4 \mathrm{mg} / \mathrm{kg} \mathrm{PO} \mathrm{q} / 24 \mathrm{~h} \times 28$ days) (Doximicina ${ }^{\circledR}$, Labodec, Peru) (van Praag 2014; Varga 2014). Also, fluid therapy using Lactated Ringer's $\left(100 \mathrm{ml} / \mathrm{kg}\right.$ SC) (Hartmann's solution ${ }^{\circledR}$, Baxter, Colombia) was given and a nutritional supplement was prescribed (Hemolitan $\mathrm{Pet}^{\circledR}$, Vetnil, Brazil) during 30 days. Pain management was administered using flunixin meglumine (1 mg/kg IM q/24h x 3 days) (Flunixin ${ }^{\circledR}$, Genfar, Colombia) and then tramadol (10mg/kg PO $\mathrm{q} / 12 \mathrm{~h} \quad \mathrm{x} \quad 7$ days) (Tramadol $^{\circledR}$, John Martin, Argentina) (Morrisey and Carpenter, 2012). Moreover, if a patient showed any other condition (e.g. constipation), it received additional medication targeting such problem (e.g. gastroprokinetic agents).

Table 3. Indirect Hemagglutination (IHA) test results.

\begin{tabular}{lcccc}
\hline & Case 1 & Case 2 & Case 3 & Case 4 \\
\hline $\lg$ titer (IHA without 2ME) & $1 / 64$ & $1 / 128$ & $1 / 32$ & $1 / 128$ \\
$\lg$ titer (IHA with 2ME) & $1 / 64$ & $\mathrm{NA}^{*}$ & $1 / 16$ & $1 / 32$ \\
\hline $\mathrm{NA}^{*}=$ Non-assessed & & & &
\end{tabular}

\section{DISCUSSION}

To the authors' knowledge, this article reports the presence of antibodies against Toxoplasma gondii in clinically ill pet rabbits (Oryctolagus cuniculus) in Peru for the first time. Previous research in Peru has reported the presence of antibodies against $T$. gondii in other domestic animal species such as in dog (Canis lupus familiaris), sheep (Ovis aries), pig (Sus scrofa), llama (Lama glama), alpaca (Vicugna pacos), and cat (Felis catus) (Suárez-Aranda et al., 2000; Ruíz et al., 2012; Angulo et al., 2014; Cerro et al., 2014; ChávezVelásquez et al., 2014; Pinedo et al., 2014; Bernal et al., 2015). Moreover, toxoplasmosis is a prevalent disease in Peruvian human population (Maguiña et al., 2004). From a public health perspective, it should be highlighted that people handling or eating raw or undercooked meat from infected rabbits might get toxoplasmosis (Lennox and Kelleher, 2009; Varga, 2014). Hence, based on our findings it is strongly recommended to assess the prevalence of $T$. gondii in rabbits bred for human consumption. Furthermore, as other small mammals (e.g. hedgehogs, ferrets, guinea pigs, pot-bellied pigs, sugar gliders) kept as exotic pets are susceptible to toxoplasmosis, this disease should be considered among differential diagnosis for such species.

The observed prevalence of clinical toxoplasmosis reported in this study agrees with Dubey et al. (1992) who signaled such kind of presentation in rabbits is considered rare. Despite the diagnostic test kit used in the described cases has not specifically been validated for rabbits, the same technique (i.e. Indirect Hemagglutination) has previously been employed in 
lagomorphs (e.g. rabbits and hares) (Ahmmed et al., 2011; Luo et al., 2017). The seropositive rabbits analyzed did not live with cats and all of them were fed diets including fresh vegetables. Based on this, the most likely source of infection is postulated to be the ingestion of vegetables contaminated with cat feces containing $T$. gondii oocysts, as suggested by Dubey et al. (1992). All seropositive rabbits were adult or aged animals. According to what is described by van Praag (2014), such animals may have been chronically infected with toxoplasmosis and presented with an acute episode, potentially due to stress or immunosuppression associated with disease or aging. Active infection (expressed by the detection of IgM) was diagnosed only in one patient. Most patients were female, but association between disease and gender was not statistically assessed due to the limited sample size. In most presented cases, clinical disease progressed to death or humane euthanasia of animals, due to poor prognosis and lack of therapeutic success. Mean survival time was less than one week. These findings agree with the high mortality rate and poor prognosis described by van Praag (2014) for acute toxoplasmosis. Unfortunately, post mortem examination was not authorized in any case. Consequently, a definitive diagnosis of toxoplasmosis could not be fully established by means of highly sensitive and specific techniques such as histopathology and PCR.

With regard to increased creatinine, van Praag (2014) has described it as commonly recorded in rabbits with toxoplasmosis. However, it should not be considered a main characteristic of this disease. The most frequent reason for patient consultation was difficulty for walking (2/4), whereas the most commonly found clinical sign was myalgia (diagnosed by palpation of forelimb and hindlimb muscles and observation of response suggesting pain) (4/4). Hyperthermia and hypothermia were observed in $50 \%$ and $25 \%$ of toxoplasmosis cases, respectively; and poor body condition was recorded in $75 \%$ of patients. Based on clinical presentation of paresis and poor body condition, encephalitozoonosis (a disease previously reported in rabbits in Lima, Peru) should be considered as a differential diagnosis (Chilón, 2014; van Praag, 2014). However, diagnostic test for encephalitozoonosis is not currently available in Peru. Additionally, in two cases vertebral alterations were detected which may explain the development of paresis but not hyperthermia and other observed clinical signs. Finally, constipation observed in one of the patients (i.e. Case 4) might be associated to pain as suggested by Meredith (2008), and this would have worsened the health status of the animal leading to its death.

\section{CONCLUSIONS}

For the first time in Peru, antibodies against $T$. gondii were detected in rabbits (Oryctolagus cuniculus) presenting clinical signs suggesting toxoplasmosis. Further studies regarding the seroprevalence of toxoplasmosis in rabbits in Peru are required for a better understanding of its epidemiology and potential risk to human health.

\section{ACKNOWLEDGEMENTS}

The authors acknowledge Jennifer Cohen for reviewing and checking the English in this manuscript.

\section{CONFLICT OF INTEREST}


The authors certify that they have no affiliations with or involvement in any organization or entity with any financial or non-financial interest in the subject matter or materials discussed in this manuscript.

\section{REFERENCES}

AGHWAN, S.S.; AL-TAEE, A.F.; SULIMAN, E.G. Detection of Toxoplasma gondii infection in rabbits by using multiple techniques. Iraqi Journal of Veterinary Sciences, v.24, n. 2, p. $65-69,2010$

AHMMED, N.E.; EL-AKABAWY, L.M.; RAMADAN, M.Y. et al. Seroprevalence of Toxoplasma gondii in rabbits in Egypt. Benha Veterinary Medical Journal, v.1, p. 191-192, 2011

ALMERÍA, S.; CALVETE, C.; PAGÉS, A. et al. Factors affecting the seroprevalence of Toxoplasma gondii infection in wild rabbits (Oryctolagus cuniculus) in Spain. Veterinary Parasitology, v.123, p. 265-270, 2004

ALVARADO-ESQUIVEL, C.; ALVARADO-ESQUIVEL, D.; VILLENA, I. et al. Seroprevalence of Toxoplasma gondii infection in domestic rabbits in Durango State, Mexico. Preventive Veterinary Medicine, v. 111, p. 325328,2013

ANGULO, J.; CASAS, G.; WATANABE, $R$. et al. Seroprevalence of antibodies against Toxoplasma gondii in alpacas of a breeding centre in Cusco, Peru [in Spanish]. Revista de Investigaciones Veterinarias del Perú, v. 25, n. 1, p. 6569,2014

ASHMAWY, K.I.; ABUAKKADA, S.S.; AWAD, A.M. Seroprevalence of antibodies to Encephalitozoon cuniculi and Toxoplasma gondii in farmed domestic rabbits in Egypt. Zoonoses and Public Health, v. 58 , n. 5 , p. $357-$ 364, 2011

BARAKAT, A.M.A. Some diagnostic studies on male New Zealand rabbit experimentally infected with Toxoplasma gondii strain. Global Veterinaria, v. 1, n. 1, p.17-23, 2007

BERGMANN, V.; HEIDRICH, R.; KIUPEL, H. Acute toxoplasmosis outbreak in rabbit flocks. [in German]. Angewandte Parasitologie, v. 21, n. 1, p. $1-6,1980$

BERNAL, D.P.; SUÁREZ, F.; HUANCA, $W$. et al. Prevalence of sheep toxoplasmosis in two regions in Puno, Peru [in Spanish]. Revista de Investigaciones Veterinarias del Perú, v. 26, n. 2,p. 291-295, 2015

BLACK, M.W.; BOOTHROYD, J.C. Lytic cycle of Toxoplasma gondii. Microbiology and Molecular Biology Reviews, v. 64, n. 3, p. 607-623, 2000

BOWMAN DD, HENDRIX CM, LINDSAY DS, BARR SC (2002) The Protozoa. In: Bowman DD, Hendrix CM, Lindsay DS, Barr SC (eds) Feline Clinical Parasitology, 1st edn. lowa State University Press, Ames, lowa, USA, pp 3-82.

CARLSON-BREMER, D.; COLEGROVE, K.M.; GULLAND, F.M.D. et al. Epidemiology and pathology of Toxoplasma gondii in free-ranging California Sea Lions. Journal of Wildlife Diseases, v. 51, n. 2, p. 362373, 2015

CENCI-GOGA, B.T.; ROSSITTO, P.V.; SECHI, P. et al. Toxoplasma in animals, food, and humans: an old parasite of new concern. Foodborne Pathogens 
and Disease, v. 8, n. 7, p. 751-762, 2011

CERRO, L.; RUBIO, A.; PINEDO, R. et al. Seroprevalence of Toxoplasma gondii in cats (Felis catus, Linnaeus 1758) living in Lima, Peru. Brazilian Journal of Veterinary Parasitology Jaboticabal, v. 23, n. 1, p. 90-93, 2014

CHÁVEZ-VELÁSQUEZ, A.; AGUAFOMARTÍNEZ, A.; ORTEGA-MORA, L.M. et al. Toxoplasma gondii and Neospora caninum seroprevalences in domestic South American camelids of the Peruvian Andes. Tropical Animal Health and Production, v. 46, p. 11411147,2014

CHILÓN, V.J. Seroprevalence of Encephalitozoon cuniculi in pet rabbits in Lima [in Spanish]. 2014. Lima, 57p. Thesis (Veterinary Physician Professional Title) - Universidad Nacional Mayor de San Marcos.

DUBEY, J.P.; BROWN, C.A.; CARPENTER, J.L. et al. Fatal toxoplasmosis in domestic rabbits in the USA. Veterinary Parasitology, v. 44, p. 305-309, 1992

DUBEY, J.P.; JONES, J.L. Toxoplasma gondii infection in humans and animals in the United States. International Journal for Parasitology, v. 38, p. 1257-1278, 2008

FISHER, P.G.; CARPENTER, J.W. Neurologic and musculoskeletal diseases. In: QUESENBERRY, K.E.; CARPENTER, J.W. Ferrets, rabbits, and rodents clinical medicine and surgery. 3.ed. St. Louis, Missouri : Elsevier Saunders, 2012. p. 246-256.

FLEGR, J.; PRANDOTA, J.; SOVICKOVA, M. et al. Toxoplasmosis A global threat. Correlation of latent toxoplasmosis with specific disease burden in a set of 88 countries. PLoS ONE, $\quad 9(3)$ : $\quad$ e90203. doi:10.1371/journal.pone.0090203, 2014

HARKNESS, J.E.; TURNER, P.V.; VANDEWOUDE, $S$. et al. Case reports. In_. Harkness and Wagner's Biology and Medicine of Rabbits and Rodents. 5.ed. Ames, lowa : Blackwell Publishing, 2010a,p. 397-422.

HARKNESS, J.E.; TURNER, P.V.; VANDEWOUDE, $S$. et al. Clinical Procedures. In . Harkness and Wagner's Biology and Medicine of Rabbits and Rodents. 2.ed. Ames, lowa : Blackwell Publishing, 2010b, p. 107-193.

HUERKAMP, M.J. The Rabbit. In: BALLARD, B.; CHEEK, R. Exotic Animal Medicine for the Veterinary Technician, 1.ed. Ames, lowa: Blackwell Publishing, 2003, p. 191-226.

LENNOX, A.M.; KELLEHER, S. Bacterial and parasitic diseases of rabbits. Veterinary Clinics of North America Exotic Animal Practice, v. 12, p. 519-530, 2009

LUO, H.; LI, K.; SHAHZAD, M. et al. Seroprevalence of Toxoplasma gondii infection in wild boars, wild rabbits, and wild chickens in Hubei Province, China. Korean Journal of Parasitology, v. 55, n. 1 , p. $85-88,2017$

MAGUIÑA, C.; SOTO, L.; ROJAS, M.E. et al. Pet Diseases in humans. Updated review [in Spanish]. Revista de la Sociedad Peruana de Medicina Interna, v. 17, n. 1, p. 17-26, 2004

MÉNDEZ, A.; MARTÍNEZ, I.; SAUCEDO, B. et al. Toxoplasmosis outbreak in a private collection of squirrel monkeys (Saimiri sciureus) in Cuernavaca, 
Mexico.Veterinaria México, v. 42, n. 2, p. $115-123,2011$

MENG, Q.F.; WANG, W.L.; NI, X.T. et al. Seroprevalence of Encephalitozoon cuniculi and Toxoplasma gondii in domestic rabbits (Oryctolagus cuniculus) in China. Korean Journal of Parasitology, v. 53, n. 6, p. 759-763, 2015

MEREDITH, A.L. Gastrointestinal disease in the rabbit. In: $33^{\mathrm{RD}}$ WORLD SMALL ANIMAL CONGRESS, 2008, Dublin, Ireland. Proceedings... Dublin, Ireland: World Small Animal Veterinary Association (WSAVA) / Federation of Companion Animal Veterinary Association (FECAVA), 2008. p.262264.

MORRISEY, J.K.; CARPENTER, J.W. Formulary. In: QUESENBERRY, K.E.; CARPENTER, J.W. Ferrets, rabbits, and rodents clinical medicine and surgery. 3.ed. St. Louis, Missouri : Elsevier Saunders, 2012, p. 566-575.

MUÑOZ-ZANZI, C.A.; FRY, P.; LESINA, B. et al. Toxoplasma gondii oocystspecific antibodies source of infection. Emerging Infectious Diseases, v. 16, n. 10 , p. 1591-1593, 2010

NASIRI, V.; TEYMURZADEH, S.; KARIMI, G. et al. Molecular detection of Toxoplasma gondii in snakes. Experimental Parasitology, v. 169, p. 106-106, 2016

PERCY, D.H.; BARTHOLD, S.W. Rabbits. In__. Pathology of laboratory rodents and rabbits. 3.ed. Ames, lowa : Blackwell Publishing, 2007, p. 253-307.

PINEDO, K.; CHÁVEZ, A.; RIVERA, H. et al. Frequency of Toxoplasma gondii and Neospora caninum in vicugnas (Vicugna vicugna) from Peruvian Central
Andes

using

Indirect

Immunofluorescense and Indirect ELISA techniques [in Spanish]. Revista de Investigaciones Veterinarias del Perú, v. 25 , n. 1 , p. $70-76,2014$

RUÍZ, N.; CASAS, E.; SUÁREZ, F. et al. Frequency of antibodies against Neospora caninum and Toxoplasma gondii in dogs with clinical signs of neuromuscular disease [in Spanish]. Revista de Investigaciones Veterinarias del Perú, v. 23, n. 4, p. 441-447, 2012

SUÁREZ-ARANDA, F.; GALISTEO JR., A.J.; HIRAMOTO, R.M. et al. The prevalence and avidity of Toxoplasma gondii IgG antibodies in pigs from Brazil and Peru. Veterinary Parasitology, v. 91, n. $1-2$, p. 23-32, 2000

TORREY, E.F.; YOLKEN, R.H. Toxoplasma gondii and Schizophrenia. Emerging Infectious Diseases, v. 9, $\mathrm{n}$. 11, p. 1375-1380, 2003

VAN PRAAG, E. Toxoplasmosis, an unrecognized parasitosis in rabbits. [Internet]. 2014. [cited 2016 oct 26]; Available in: http://www.medirabbit.com/ EN/ Neurology/ Toxoplasm/ Toxo_rab_en.pdf

VARGA, M. Textbook of rabbit medicine. 2.ed. China : Butterworth Heinemann, 2014. 494 p. 